\title{
Surfactant Protein B in Human Fetal Lung: Developmental and Glucocorticoid Regulation
}

\author{
MICHAEL F. BEERS, HENRY SHUMAN, HELEN G. LILEY, JOANNA FLOROS, \\ LINDA W. GONZALES, NING YUE, AND PHILIP L. BALLARD \\ Institute for Environmental Medicine, University of Pennsylvania, Philadelphia, Pennsylvania [M.F.B., \\ H.S.], Department of Pediatrics, Harvard University Medical School, Boston, Massachusetts 02115 \\ [H.G.L], Department of Cellular and Molecular Physiology, Pennsylvania State University College of \\ Medicine, Hershey, Pennsylvania 17033 [J.F.], and Department of Pediatrics, University of Pennsylvania, \\ Children's Hospital of Philadelphia, Philadelphia, Pennsylvania 19104 [L.W.G., N.Y., P.L.B.]
}

\section{ABSTRACT}

\begin{abstract}
Pulmonary surfactant protein B (SP-B) enhances phospholipid film formation in vitro and is essential for normal surfactant function in vivo. We examined human fetal lung before and during explant culture for content and cellular localization of SP-B mRNA and protein. SP-B mRNA was low in preculture specimens (18-20 wk) but hybridization signal increased over epithelial cells during culture and was enhanced by dexamethasone treatment $(10 \mathrm{nM})$. SP-B immunofluorescence was very low in preculture specimens, increased during culture, and was uniformly intense in epithelial cells of dexamethasone-treated tissue. With a newly developed immunoassay, SP-B protein was undetectable in preculture lung ( $<2 \%$ of adult), appeared during culture ( $26 \%$ of adult), and was further increased $\sim 3$-fold by dexamethasone treatment ( $86 \%$ of adult); lung tissue of two newborn infants contained 7-9-fold more SP-B than is found in the adult. Using Western blot with enhanced chemiluminescence, mature SP-B was undetectable in 16-wk specimens but was
\end{abstract}

present in $19-24-w k$ preculture tissue at $0.2-2.9 \%$ of the adult level. By comparison, SP-B mRNA content is 14 and $50 \%$ of adult level in 19- and 24-wk lung tissue, respectively; levels increase 3-fold during culture and a further 3-fold with dexamethasone. Based on these observed differences between mRNA and protein content, we conclude that basal SP-B gene expression in epithelial cells of human fetal lung is regulated primarily at the level of translation or protein stability, whereas glucocorticoids act transcriptionally. We speculate that SP-B protein accumulates only as type II cells differentiate and acquire lamellar bodies for processing and storage of SP-B. (Pediatr Res 38: $668-675,1995$ )

SP, surfactant protein

\section{Abbreviations}

TBS, Tris-buffered saline
Pulmonary surfactant isolated from bronchoalveolar lavage fluid contains a variety of lipids and proteins. Three SP have been identified that influence surfactant structure, function, or metabolism. SP-A is a hydrophilic protein of $28-36-\mathrm{kD}$ monomer size that has a number of demonstrated effects on surfactant in vitro both alone and interacting with other surfactant proteins. SP-B and SP-C are lipophilic proteins of approximately 8 and $4 \mathrm{kD}$, respectively, that co-isolate with surfactant lipids. Both of these proteins enhance the rate of phospholipid film formation and improve the surface activity of lipid mixtures in vivo (reviewed in Ref. 1).

SP-B appears to be critically important for surfactant function in vivo. Antibodies to SP-B inactivate a replacement surfactant prepared from pig lungs and cause severe respiratory

Received November 17, 1994; accepted May 9, 1995.

Correspondence: Philip L. Ballard, Room 8073, Children's Hospital of Philadelphia, Philadelphia PA 19104.

Supported by National Institutes of Health Program Project Grant HL 19737 and HL 34788 . distress when instilled into the trachea of newborn animals or inoculated intraperitoneally into adult mice (2-4). In pulmonary function studies with preterm rabbits, Rider et al. (5) found that the activity of lipid-SP-B preparations was equivalent to that of natural surfactant. Recently, Nogee et al. (6) described the absence of SP-B mRNA and protein in lungs of two infants with congenital alveolar proteinosis who died in infancy of respiratory failure.

There is considerable information regarding developmental and hormonal regulation of SP-B mRNA. The mRNA is detected as a single transcript in human fetal lung in as early as 12 wk of gestation, and levels increase throughout the second trimester, reaching $\sim 50 \%$ of the adult level at $24 \mathrm{wk}(7)$. The gene is expressed in alveolar type II and bronchiolar Clara cells of adult lung but not in other tissues $(7,8)$. SP-B gene expression is increased by glucocorticoids and cAMP in cultured explants of rat and human lung, and by in vivo glucocorticoid treatment in fetal rats and rabbits $(1,7,9-11)$. The glucocorticoid responses in human lung and NCI $\mathrm{H}-441$ cells, 
which are derived from a human lung adenocarcinoma, involve both increased rate of gene transcription and stabilization of SP-B mRNA $(12,13)$.

There is less information available about levels and regulation of SP-B protein in developing lung, particularly for the human. Weaver et al. (14) and Stahlman et al. (15) did not detect SP-B by immunohistochemistry in preculture specimens of second trimester human fetal lung, whereas immunostaining was present after $48 \mathrm{~h}$ of explant culture (14). In an earlier study Whitsett et al. (16) reported that dexamethasone treatment of cultured human fetal lung increased immunoreactive product using an antibody recognizing both SP-B and SP-C. In amniotic fluid, SP-B was not detected before $30 \mathrm{wk}$, and the concentration increased thereafter (17).

In this study we have examined the content and cellular distribution of SP-B mRNA and protein in human fetal lung before and during explant culture. We used confocal microscopy immunofluorescence, enhanced chemiluminescence of protein blots, and a newly developed immunodot assay to address the hypotheses that 1 ) SP-B protein is expressed during in vivo development with a pattern similar to that observed for mRNA content, and 2) explant culture and glucocorticoid treatment result in similar increases in both SP-B mRNA and protein content. Preliminary reports of this work have been published $(18,19)$.

\section{METHODS}

\section{Materials}

Waymouth's MB 752/1 medium was obtained from the Cell Culture Facility, University of Pennsylvania, and supplemented with penicillin $(100 \mathrm{U} / \mathrm{mL})$, streptomycin $(100 \mu \mathrm{g} /$ $\mathrm{mL})$, and Fungizone $(2.5 \mu \mathrm{g} / \mathrm{mL})$. Dexamethasone and other biochemicals were obtained from Sigma Chemical Co. (St. Louis, MO). Radioisotopes and reagents for enhanced chemiluminescence were purchased from Amersham Searle (Arlington Heights, IL), and protein molecular weight markers were obtained from Life Technologies, Inc. (Gaithersburg, MD). Human fetal lung was obtained from second trimester therapeutic abortions under protocols approved by the Committee on Human Research at the Children's Hospital of Philadelphia. Adult lung tissue was obtained from patients undergoing lobectomy, and samples of newborn lung were obtained postmortem.

\section{Explant Culture}

Fetal lung parenchyma was minced into $1-\mathrm{mm}^{3}$ bits and cultured as explants in serum-free Waymouth's medium with or without $10 \mathrm{nM}$ dexamethasone. The explants were maintained at $37^{\circ} \mathrm{C}$ in $95 \%$ air $/ 5 \% \mathrm{CO}_{2}$ on a rocker platform as previously described (20), and the medium was changed daily. Tissue explants were harvested either before culture or at various times during culture.

\section{mRNA Content}

Total RNA was isolated from lung tissue and specific mRNA content determined by cDNA hybridization using a dot blot apparatus as previously described $(7,13)$. The cDNA probes were labeled with $\left[{ }^{32} \mathrm{P}\right] \mathrm{dCTP}$ using a random primer labeling technique (oligo labeling kit; Pharmacia Biotech Inc., Piscataway, NJ). Blots were exposed to Kodak XAR film with Cronex intensifying screens (DuPont Instruments, Wilmington, $\mathrm{DE}$ ) for $1-5 \mathrm{~d}$ at $-70^{\circ} \mathrm{C}$, and the autoradiograms were scanned using a densitometer (Hoeffer GS 300, Hoeffer Scientific Instruments, San Francisco, CA). Relative densities were calculated from linear portions of the dose-response curve for each RNA sample.

\section{In Situ Hybridization}

Hybridization studies were performed with three lungs of 19-22-wk gestation. Tissue was harvested before culture (preculture) and after $3 \mathrm{~d}$ of explant culture with and without 10 $\mathrm{nM}$ dexamethasone. Tissue pieces were fixed for $1 \mathrm{~h}$ at $4^{\circ} \mathrm{C}$ in $2 \%$ paraformaldehyde, $0.2 \%$ gluteraldehyde in $\mathrm{PBS}, \mathrm{pH} 7.2$. The tissue was then incubated overnight in $30 \%$ sucrose in PBS, embedded in OCT (Tissue Tek), quick frozen in liquid nitrogen, and then stored at $-70^{\circ} \mathrm{C}$ until sectioning.

Probe preparation. Linearized plasmid DNA containing full-length human SP-B cDNA was used as template for the preparation of cRNA probe (21). The reaction was carried out as described by Promega Biotec (Madison WI) and contained DNA template $(100 \mu \mathrm{g} / \mathrm{mL})$ and $250 \mu \mathrm{Ci}$ of uridine $5-\left[{ }^{35} \mathrm{~S}\right]$ thiotriphosphate $(1100 \mathrm{Ci} / \mathrm{mol})$. Sense, for negative control, and antisense cRNA probes were generated and purified as previously described (8).

Hybridization. The methods have been previously described $(8,11,22)$. Briefly, three to five randomly chosen explants were embedded together in each block. Five $\mu \mathrm{m}$ sections were cut on a cryostat microtome and four to five sections were mounted on ovalbumin-coated glass slides. Thus, there were sections through different parts of each of several explants on each slide. The sections were rinsed in PBS, postfixed in $4 \%$ paraformaldehyde in PBS for $10 \mathrm{~min}$, then incubated in $0.3 \%$ Triton X-100 in PBS for $15 \mathrm{~min}$. The slides were then incubated with $1 \mu \mathrm{g} / \mathrm{mL}$ proteinase $\mathrm{K}$, rinsed in several changes of PBS, and then incubated in $0.25 \%$ acetic anhydride in $0.1 \mathrm{M}$ ethanolamine, then $50 \%$ formamide in $2 \times$ SSC. Hybridization was performed overnight at $50^{\circ} \mathrm{C}$ by applying $10-15 \mathrm{~mL}$ hybridization solution ( $50 \%$ formamide, $10 \%$ dextran sulfate, 2 $\times$ SSC, $0.25 \%$ ficoll, $0.25 \%$ BSA, $0.25 \%$ polyvinylpyrolidine $300,50 \mathrm{mM}$ Tris, $0.1 \%$ sodium pyrophosphate, $0.1 \%$ SDS) and $4.5 \times 10^{5} \mathrm{cpm}$ of ${ }^{35} \mathrm{~S}$-UTP-labeled riboprobe to each section. After hybridization, the slides were washed with SSC $(4 \times, 2$ $\times$, then $0.1 \times$ ) and then treated with RNase A. After stepwise dehydration in ethanol/0.3 $\mathrm{M}$ ammonium acetate, slides were dipped in Kodak NTB2 photographic emulsion for autoradiography. They were allowed to expose for $3-5 \mathrm{~d}$ at $4^{\circ} \mathrm{C}$ and were then developed, counter stained with hematoxylin and photographed under a light microscope with a $25 x$ Zeiss planar lens. Tissue from the different experimental conditions in each experiment were processed together and exposed for the same time. 


\section{Immunostaining}

Monospecific polyclonal antisera directed against bovine SP-B was produced in rabbits by injection of an organic solvent extract of bovine surfactant (Surfactant TA, Ross Laboratories). Details of the preparation and characterization of this antiserum have been previously described (23). The antiserum recognizes both the reduced (monomer) and nonreduced (dimeric) forms of bovine, human and rat mature SP-B as well as all forms of pro-SP-B containing the mature SP-B sequence. Anti-SP-B does not show cross reactivity to SP-A, SP-C, or serum proteins. Experiments used four lungs of 12-wk gestation, 1 lung of $15 \mathrm{wk}$, and 3 of $20 \mathrm{wk}$, and tissue was examined before (12-wk samples) or before and after $5 \mathrm{~d}$ of explant culture (other samples).

Lung samples were fixed with $4 \%$ paraformaldehyde in 0.1 $\mathrm{M}$ sodium cacodylate buffer ( $\mathrm{pH} 7.4$ ) and then washed in the sodium cacodylate buffer for $1 \mathrm{~h}$. The tissue was cryoprotected in $10 \%$ sucrose in $0.1 \mathrm{M}$ sodium cacodylate for $1 \mathrm{~h}, 20 \%$ sucrose in the same buffer $1 \mathrm{~h}$, and $30 \%$ sucrose in the same buffer overnight at $4^{\circ} \mathrm{C}$. The tissue was frozen in Freon 22 cooled to $-150^{\circ} \mathrm{C}$ with liquid nitrogen. The samples were mounted for cryosectioning with Polyfreeze tissue freezing medium. Cryostat sections, $8 \mu \mathrm{m}$ thick, were cut at $-20^{\circ} \mathrm{C}$, placed on gelatin/chrom-alum coated slides and air dried.

Tissue sections were immunostained based on the method of Williams et al. (24) as modified in our laboratory (25). This method utilizes two preincubations in $0.1 \%$ sodium borohydride in PBS for $5 \mathrm{~min}$ to reduce endogenous fluorescence. Staining was done by sequentially incubating sections with rabbit anti-SP-B diluted 1:500 in PBS with $0.3 \%$ Triton X-100, $3 \%$ BSA, 5\% goat serum, and finally Texas-Red conjugated goat anti-rabbit IgG (Organon Teknika, Durham, NC) diluted 1:100 in the same buffer solution. After extensive washes in PBS with and without $0.3 \%$ Triton X-100, sections were air-dried, and coverslips were sealed with Mowiol (Calbiochem, San Diego, CA).

Control slides were prepared by replacing the primary antibody with rabbit preimmune serum (diluted 1:500). All sections were examined using confocal laser fluorescence microscopy. Texas Red fluorescence was detected at an excitation wavelength of $563 \mathrm{~nm}$ and an emission wavelength greater than $625 \mathrm{~nm}$. Photographs were made with the same number of scans and exposure for all specimens.

\section{Quantitative Immunoblot Assay}

Tissue levels of SP-B protein were measured using a quantitative immunoblot assay developed in our laboratory. Seven lungs of 19-22 wk were studied before and after culture for 4-6 d. Fetal tissue was sonicated ( $6 \mathrm{~s}$ with a microtip) in a solution of protease inhibitors containing $10 \mathrm{mM}$ benzamidine, $50 \mathrm{mM} N$-ethylmaleimide, and $10 \mathrm{mM}$ phenylmethylsulfonyl fluoride. Newborn and adult lung samples were pulverized in liquid nitrogen with a mortar and pestle before sonication. Protein concentration was determined by the assay of Bradford using bovine IgG as standard (26). Samples of sonicated tissue (200 $\mu \mathrm{L}$ total volume) of known protein content were serially diluted in PBS, pH 7.5, and spotted onto a gridded nitrocellu- lose paper using a vacuum-assisted 96-well dot-blot apparatus (Bio-Rad, Rockville Center, NY). After drying, the nitrocellulose blot was blocked using $2 \%$ gelatin in TBS and washed using Tween $(0.05 \%)$ in TBS. The blots were incubated $2 \mathrm{~h}$ in a primary antibody solution consisting of anti-SP-B in TweenTBS (1:1000) followed by a $3-h$ incubation in secondary antibody solution containing an ${ }^{125}$ I-labeled goat anti-rabbit antisera $(0.1-0.2 \mathrm{mCi} / \mathrm{mL})$. The blot was washed extensively in Tween-TBS and dried. The ${ }^{125}$ I radioactivity of each spot was measured directly by $\beta$ scanning using an Ambis 4000 radioanalytic imaging detector and quantified using Ambis image analysis software. Net counts (corrected for background counts from a sample blank) were obtained for each dot, and data were collected in a Data Information File (DIF) and plotted on a semilogarithmic plot using Sigma Plot (Jandel Scientific, San Rafael, CA). Because of the problems associated with obtaining reliable protein content measurements for hydrophobic surfactant proteins (27), we chose to normalize the data to SP-B in bovine surfactant. A single preparation of bovine surfactant prepared in our laboratory (23) was used as an internal standard for all assays, and data for lung samples are expressed as percent of bovine surfactant SP-B. Assays were performed in duplicate on tissue from duplicate culture dishes and SP-B content was read from the linear portion of the standard and unknown sample curves.

\section{SDS-PAGE and Western Blot}

Lung sonicates were subjected to SDS-PAGE using TrisTricine buffer according to the method of Schaegger and von Jagow (28), and proteins were transferred electrophoretically overnight to nitrocellulose as previously described (23). After transfer, immunoblotting was performed with anti-SP-B antiserum (1:1000), and secondary goat anti-rabbit IgG antisera was conjugated with horseradish peroxidase (1:2000) (23). Color was developed using 4-chloronaphthol (Bio-Rad, Melville, NY) following the manufacturer's instructions. For analysis of preculture lung specimens, which have very low levels of SP-B, we used anti-SP-B antiserum at 1:4000 and secondary goat anti-rabbit IgG antisera at 1:10,000 and detected immunoreactive product with enhanced chemiluminesence according to the manufacturer's directions. Density of the SP-B bands was quantitated using a scanning densitometer (GS300, Hoefer Scientific Instruments, San Francisco, CA) under exposure conditions that provided a linear response to amount of loaded protein.

\section{RESULTS}

In situ hybridization. Previous studies with human lung used Northern and dot blot hybridization to determine content of SP-B mRNA during development and in explant culture. In this study we performed in situ hybridization to examine cellular distribution and relative levels of message. The overall hybridization signal with SP-B antisense probe in sections of lung before culture was similar to the background levels seen with sense probes (Fig. 1, a versus d). However, most preculture sections had some regions of increased hybridization over epithelial cells, consistent with our previous finding that mid- 

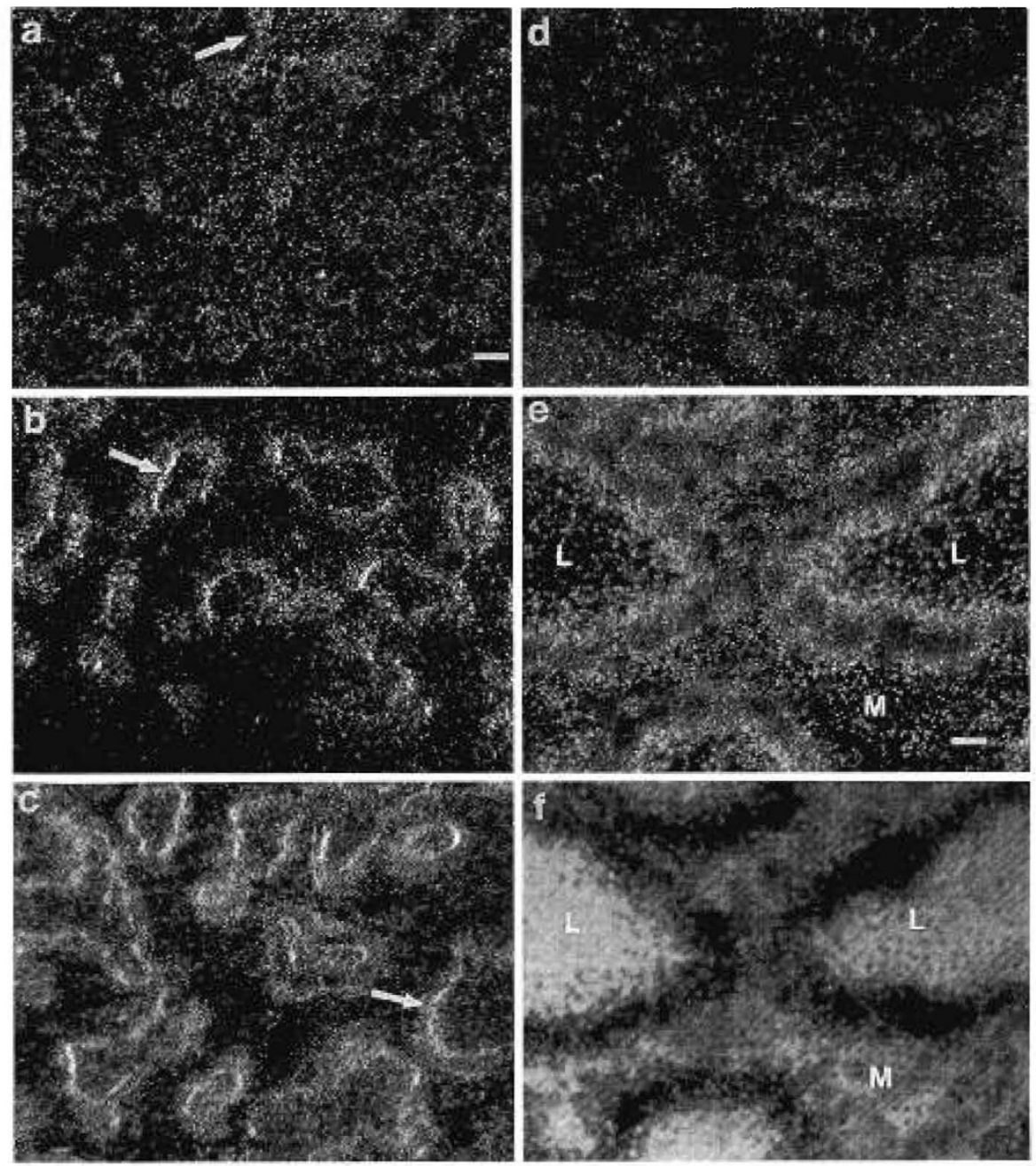

Figure 1. In situ hybridization of SP-B mRNA in frozen sections of human fetal lung. Paraformaldehyde-fixed frozen sections were hybridized to antisense ${ }^{35}$ S-labeled cRNA probe (panels $a-c, e$, and $f$ ) or to sense probe (control, panel $d$ ). Panels $a$ and $d$, before culture; $b$, after $3 \mathrm{~d}$ in culture without hormones; $c$, after $3 \mathrm{~d}$ in culture with $10 \mathrm{nM}$ dexamethasone for the last $2 \mathrm{~d}$. Arrows in panels $a-c$ denote some of the regions demonstrating specific hybridization signals over epithelial lining cells. Results shown are dark field photomicrographs where brighter areas have higher levels of SP-B mRNA. The results are typical of three experiments for each culture condition. Bar equals $25 \mu \mathrm{m}$. Panels $e$ and $f$ are higher magnification dark field and bright field micrographs, respectively, of a different area of dexamethasone-treated tissue showing in greater detail the morphology and localization of grains over epithelial cells. Bar equals $10 \mu \mathrm{m}$. $L$, lumen; $M$, mesenchyme.

trimester human fetal lung contains detectable SP-B RNA, albeit at a fraction of the levels found in adult lung.

Levels of hybridization over epithelial cells were clearly increased after $3 \mathrm{~d}$ of explant culture (Fig. 1b) compared with preculture tissue, whereas the signal over the surrounding mesenchymal cells was not above background hybridization seen with sense probes (Fig. 1d). In sections of dexamethasone-treated tissue (Fig. 1, $c, e$, and $f$ ), the hybridization signal was increased in intensity over most epithelial cells compared with control tissue. The photomicrographs shown are representative of experiments with fetal lung of 19-22 wk of gestation. By bright field microscopy (Fig. 1f), lung morphology was similar to that previously described (20).

Immunostaining. Immunoreactive SP-B was undetectable or at very low levels in all preculture fetal lungs (12-20-wk gestation). Areas of staining were only occasionally observed in the sections and were of low intensity.

Effects of culture and dexamethasone were examined in experiments with three separate lungs. In the experiment illus- trated in Fig. 2, preculture 20-wk tissue had a low level of staining of some epithelial cells (Fig. $2 a$ ). After $5 \mathrm{~d}$ of explant culture without serum or hormones, the intensity of immunostaining (at the same dilution of antibody) was increased, and most epithelial cells were positive (Fig. $2 b$ ). Dexamethasone treatment of explants for $5 \mathrm{~d}$ resulted in very intense staining of epithelial cells and occasional intraluminal staining. Signal over the mesenchyme (Fig. $2 c$ ) was minimal and resembled the background staining seen with preimmune serum (Fig. $2 d$ ). Results were similar with the other two lungs.

Quantitative immunoblot assay. We developed and characterized an immunoassay for SP-B using polyclonal antiserum raised against an organic solvent extract of bovine surfactant. The intraassay and interassay coefficients of variation were $3.7 \%(n=16)$ and $9.6 \%(n=8)$, respectively. Serial dilutions of sonicated tissue samples consistently yielded curves parallel to a standard curve prepared with bovine surfactant (Fig. 3, a and $b$ ) and the shape of the standard curve was not affected by addition of non-lung protein (rat brain homogenate, not 

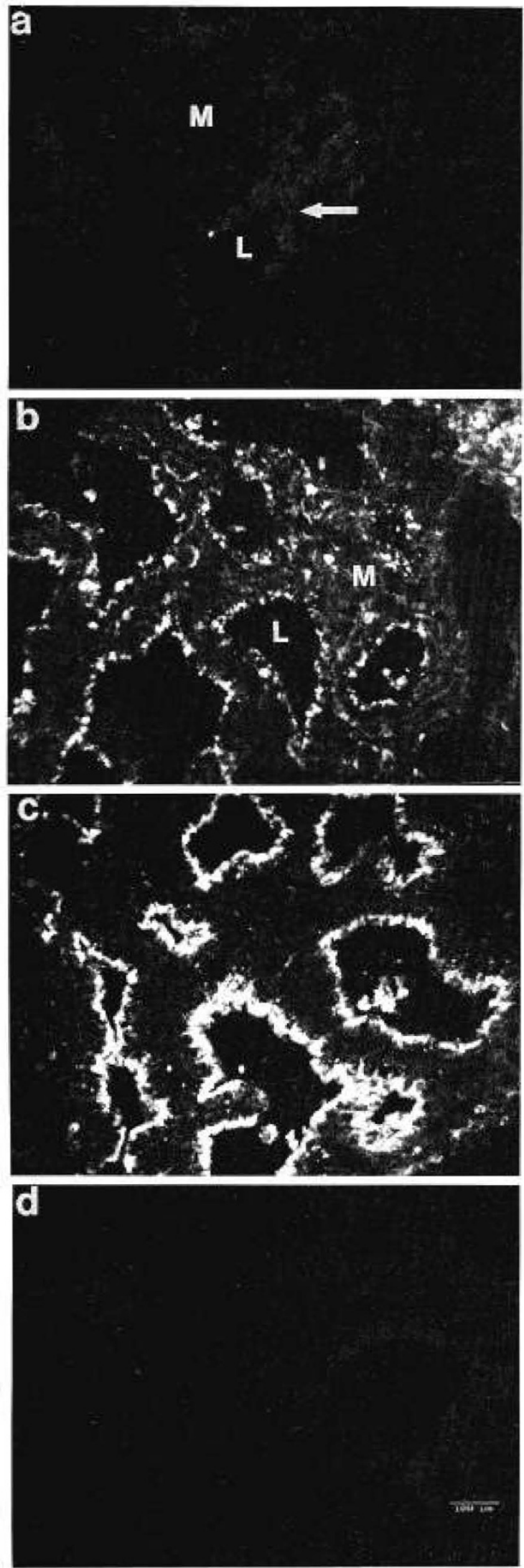

Figure 2. SP-B immunostaining of a 20 -wk gestation fetal lung. Tissue was fixed, sectioned, and exposed to 1:500 dilution of immune serum (panels $a-c$ ) or nonimmune serum (panel $d$ ). $a$, Preculture; $b$, after $5 \mathrm{~d}$ in culture without hormones; $c$ and $d$, after $5 \mathrm{~d}$ in culture with $10 \mathrm{nM}$ dexamethasone. Weak, scattered staining is seen in preculture tissue (e.g. arrow). Most epithelial cells of cultured tissue are positive for SP-B with increased intensity and occurrence of staining after dexamethasone treatment. Bar $=100 \mu \mathrm{m}$. $L$, lumen; $M$, mesenchyme. a

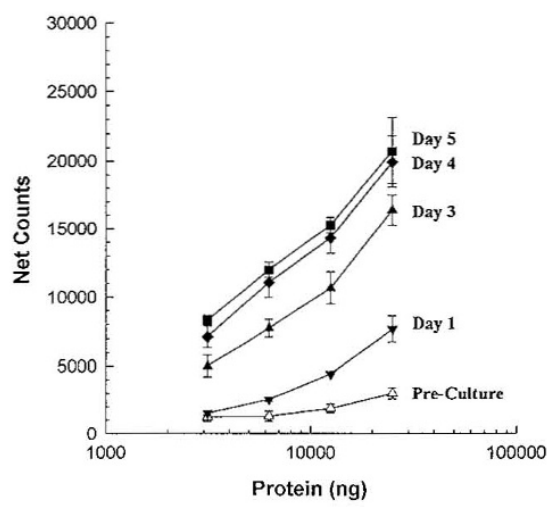

b

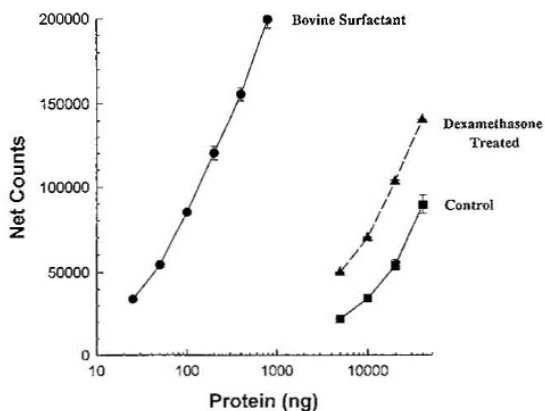

Figure 3. SP-B content assessed by quantitative immunoblot assay. (a) Effect of explant culture. A representative experiment for relative SP-B content in a 21-wk fetal lung cultured in the absence of hormones is shown. Net counts/min (mean $\pm \mathrm{SE}$ ) of duplicate serial dilutions of duplicate lung samples $(n=4)$ from each time point are plotted on a semilog scale $v s$ total protein content. The highest amounts of protein used represent the limit for application to the filter. $b$, Effect of dexamethasone on SP-B. Data are shown for known amounts of bovine surfactant standard (closed circles, mean of duplicates \pm range) and serial dilutions of sonicates from a 20 -wk gestation fetal lung cultured for $5 \mathrm{~d}$ in the presence (open boxes) or absence (closed boxes) of $10 \mathrm{nM}$ dexamethasone.

shown). Under our usual conditions of tissue preparation and assay, an SP-B content equivalent to $0.02 \%$ of bovine surfactant could be reliably measured.

SP-B protein was below the level of detectability by immunoassay in all samples of preculture lung (19-22-wk gestation, $n=7)$. SP-B became quantifiable in control tissue after explant culture, achieving a level of $0.3 \%$ of bovine surfactant after 5 $\mathrm{d}$ (Table 1). Data from one experiment in which tissue was assayed daily during culture are shown in Figure 3. SP-B concentration increased progressively $(>10$-fold) between $\mathrm{d} 0$ and 4 of culture.

In seven experiments tissue was cultured with and without dexamethasone for $4 \mathrm{~d}$. In each experiment SP-B concentration was increased by hormone treatment and the mean value was 3 -fold greater than control. The induced levels were comparable to those found in sonicate of adult human lung (Table 1).

Western blot. We initially examined immunoreactive SP-B forms on Western blots using horseradish peroxidaseconjugated secondary antibody detected by color development (Fig. 4). Loading up to $30 \mu \mathrm{g}$ of protein with this system we did not detect immunoreactive protein in preculture fetal lung sonicates (lane 1). In cultured tissue, however, SP-B was 
Table 1. Content of $S P-B m R N A$ and protein in lung tissue

\begin{tabular}{|c|c|c|c|c|}
\hline \multirow[b]{2}{*}{ Tissue } & \multirow[b]{2}{*}{$n$} & \multicolumn{2}{|c|}{ SP-B protein content } & \multirow{2}{*}{$\begin{array}{c}\begin{array}{c}\text { SP-B mRNA } \\
\text { content }\end{array} \\
(\% \text { adult })^{*}\end{array}$} \\
\hline & & $\begin{array}{l}\text { (\% bovine } \\
\text { surfactant) }\end{array}$ & ( $\%$ adult $)$ & \\
\hline Preculture & 7 & $\mathrm{ND} \dagger$ & $<2 \dagger$ & $24.5 \pm 3.9 \ddagger$ \\
\hline Control cultured & 7 & $0.30 \pm 0.06$ & 25.6 & $86.9 \pm 16.9$ \\
\hline $\begin{array}{l}\text { Dexamethasone- } \\
\text { treated }\end{array}$ & 7 & $1.01 \pm 0.28$ & 86.3 & $182.0 \pm 34.8 \ddagger$ \\
\hline Adult & 5 & $1.17 \pm 0.22$ & 100 & 100 \\
\hline
\end{tabular}

SP-B content was determined by immunoassay of serial dilutions of lung sonicate. Fetal tissue (19-22-wk gestation) was examined before (preculture) and after $5 \mathrm{~d}$ culture as explants with $10 \mathrm{nM}$ dexamethasone or without (control cultured).

* \pm Data from Liley et al. (7).

$\uparrow \mathrm{ND}$, not detected: limit of quantification for immunoblot assay $=0.02 \%$ of bovine surfactant value. By Western blot with enhanced chemiluminescence five of six samples at $19-21 \mathrm{wk}$ had $\leq 1.1 \%$ of adult SP-B level (Fig. 5).

$\$ p<0.05$ vs control cultured (paired t-test).

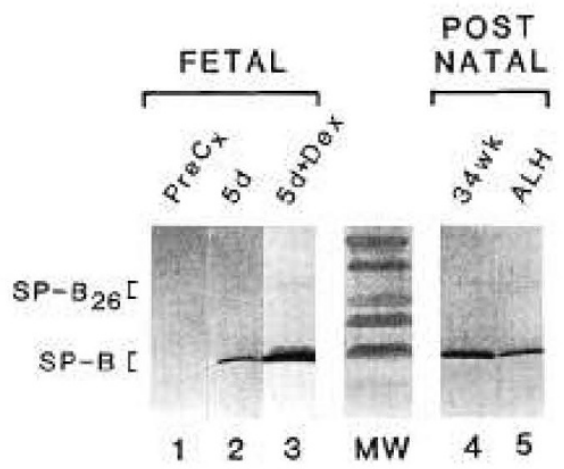

Figure 4. Western blot analysis of SP-B in human lung tissue. Sonicates prepared from fetal lung (21-wk gestation), 34-wk newborn, and adult lung were subjected to Tris-Tricine SDS-PAGE using a 16.5\% resolving gel. Electrophoresed proteins were transferred to nitrocellulose and probed with anti-SP-B antiserum. Bands were visualized with anti-rabbit IgG antisera conjugated with horseradish peroxidase and 4-chloronaphthol. Lane 1, fetal lung before culture ( reC $\mathrm{Cx}, 25 \mu \mathrm{g}$ of protein); lane 2, fetal lung after $5 \mathrm{~d}$ in culture without hormones ( $5 \mathrm{~d}, 20 \mu \mathrm{g}$ of protein); lane 3 , fetal lung after $5 \mathrm{~d}$ in culture with dexamethasone $(5 d+D x, 20 \mu \mathrm{g}$ of protein); lane 4,34-wk newborn lung (34wk, $15 \mu \mathrm{g}$ of protein); lane 5, adult lung $(A L H, 30 \mu \mathrm{g}$ of protein). $M W=$ low molecular mass markers: $43,29,18.4,14.3,6.2$, and 2.5 $\mathrm{kD}$. Results are representative of four experiments.

present as mature monomer $(\sim 6.5 \mathrm{kD})$ with small amounts of precursor forms $(\sim 26$ and $42 \mathrm{kD})$ detected in samples with increased SP-B content; this pattern was similar to that found with newborn and adult lung. The content of immunoreactive SP-B detected in fetal tissue by Western blot was qualitatively greater after dexamethasone treatment in agreement with findings by immunostaining and immunoassay.

The failure to detect SP-B protein by immunostaining in second trimester human fetal lung was surprising since as previously reported there is substantial SP-B mRNA at this stage of development (Table 1). To further examine preculture tissue we prepared Western blots using increased amounts of protein in the gels $(200 \mu \mathrm{g})$ and enhanced chemiluminesence for detection. As shown in Figure $5 a$, faint bands of mature SP-B were detected in preculture lung specimens of 21-24-wk gestation. Newborn and adult samples, with lower amounts of protein loaded, showed strong bands corresponding to mature
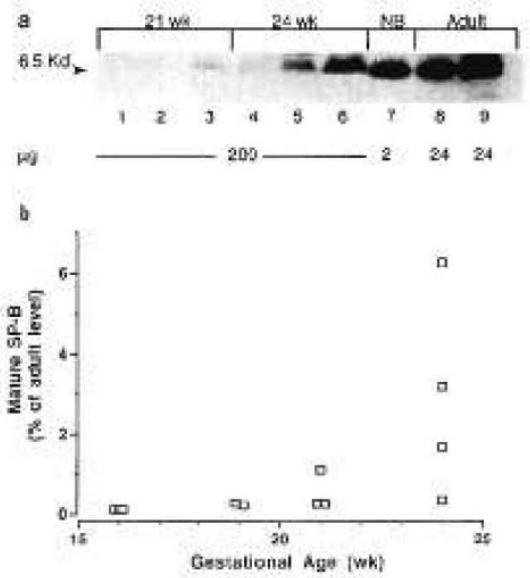

Figure 5. Western blot analysis of SP-B in preculture fetal lung using enhanced chemiluminesence. (a) Representative blot showing mature SP-B. Lanes 1-3, 21-wk gestation samples, $200 \mu \mathrm{g}$ of protein each; lanes 4-6, 24-wk gestation samples, $200 \mu \mathrm{g}$ of protein each; lane 7, newborn specimen, $2 \mu \mathrm{g}$ of protein; lanes 8 and 9 , adult lungs, $24 \mu \mathrm{g}$ of protein each. $(b)$ Developmental pattern for mature SP-B in human fetal lung. Data were obtained from densitometric scans of Western blots, such as shown in $a$, and are individual values for 12 specimens between 16 and 24 wk. Densitometric data are normalized for amount of total protein loaded on the gel, and results are presented as percent of the mean value for five adult specimens. Mature SP-B was not detected in the 16 -wk samples $(<0.1 \%$ of adult level) but was present in all other specimens. One sample of 19 -wk lung had $13.1 \%$ of the adult value and is not included in the figure. Two newborn lung samples contained 7- and 9-fold more SP-B than the mean value for adult samples (not shown).

SP-B. Fetal samples also showed a band at $\sim 15 \mathrm{kD}$ (not shown) which may represent a proteolytic cleavage product of precursor SP-B. The films from this and other blots were scanned, and data for levels of mature SP-B protein are shown in Figure $5 b$. Mature SP-B was undetectable in 16-wk tissue $(<0.1 \%$ of adult level) but was present in all samples of $19-24$ wk gestation with higher levels present at 24 wk (mean $2.9 \%$ of adult level).

To further study the relationship between content of SP-B mRNA and protein, we measured both parameters in three lungs of 21-23-wk gestation. At the beginning of culture the content of SP-B mRNA and immunoreactive protein (by Western analysis with enhanced chemiluminesence) was $22.4 \pm$ $4.9 \%$ and $1.4 \pm 0.3 \%$ of the adult value, respectively $(p<$ 0.01 ). After $5 \mathrm{~d}$ of explant culture without hormone SP-B mRNA increased $2.4 \pm 0.4$-fold and SP-B protein increased $23.7 \pm 4$-fold $(p<0.01)$. Exposure of tissue to dexamethasone further increased SP-B mRNA content $2.4 \pm 0.2$-fold and SP-B protein $3.2 \pm 0.5$-fold (NS) on d 5 . In the same experiments both SP-A mRNA and protein were at or below the limits of detection at the beginning of culture, and both increased $\geq 50$-fold during $5 \mathrm{~d}$ of culture without hormone, confirming previous observations $(9,30,31)$.

\section{DISCUSSION}

Previous work has indicated that SP-B mRNA content in human lung is both developmentally and hormonally regulated; however, there has been little information on cellular localization of expression or content of SP-B protein in fetal lung. It has been uncertain whether the stimulatory effects of explant 
culture and glucocorticoid treatment on SP-B mRNA content involved a relatively uniform response by all epithelial cells and whether SP-B protein was increased proportionally to mRNA. In this study, we addressed these issues using in situ hybridization and immunocytochemical techniques.

By in situ hybridization we found low levels of SP-B mRNA in preculture second trimester lung tissue, consistent with the previous finding by in vitro hybridization $(\sim 5$ to $15 \%$ of adult level for 12-20-wk tissue) (7). Hybridization signal was detected in only some of the developing tubules in second trimester preculture tissue and appeared to be localized to lining cells. This pattern presumably reflects regional differences in expression of the SP-B gene, possibly related to budding of saccules. In adult human lung, SP-B mRNA is present in both type II and bronchiolar Clara cells (8).

Two previous studies did not detect immunoreactive SP-B in preculture second trimester tissue using horseradish peroxidase immunohistochemistry $(14,15)$. Our observation of very low but detectable specific immunofluorescence in some areas of preculture tissue may reflect increased sensitivity of immunofluorescence detected by laser confocal microscopy. We were unable to detect immunoreactive SP-B protein in preculture tissue by immunoassay, but low levels were detected by Western blot after loading maximal possible amounts of protein and using highly sensitive chemiluminesence for detection. The content of SP-B protein increased during the last part of the second trimester with a pattern comparable to that found for SP-B mRNA content (7). The possible function if any of very low levels of mature SP-B in some epithelial lining cells as early as 19 wk of gestation is unknown but is probably not related to surfactant, because lamellar bodies do not normally appear until $\sim 24$ wk of gestation and surfactant is not detected in amniotic fluid until $\sim 30 \mathrm{wk}(17)$. We found high levels of SP-B in term newborn infants compared with the adult which may reflect a relatively greater proportion of type II and possibly Clara cells, increased synthetic rate, and/or decreased degradation.

After explant culture of fetal lung for several days without serum or hormones, the percentage of positive cells and intensity of both hybridization and immunostaining increased. The increased expression of SP-B and its mRNA was clearly localized to epithelial cells lining the developing saccules, confirming a previous observation by immunocytochemistry (14). Some immunoreactive material was observed in the airway lumens which could represent secreted protein and/or desquamated epithelial cells. Although it is not yet determined whether SP-B in explants is incorporated into lamellar bodies, the previous finding that SP-A stimulates the rate of in vitro film formation by lamellar bodies from cultured human fetal lung supports this possibility (29).

It is known that explant culture per se causes precocious differentiation of type II cells with appearance of lamellar bodies and increasing content of surfactant lipids and mRNAs for SP-A and SP-B. This process is mediated at least in part by endogenous prostaglandins and by cAMP which increases during culture $(30,31)$. Our data indicate that the increase in immunoreactive SP-B protein during culture is $\sim 20$-fold, whereas the increase in mRNA content during culture is $\sim 3$ - fold. By contrast, SP-A mRNA and protein increase proportionally during culture (9). The greater abundance of SP-B mRNA than protein in preculture tissue and the manyfold accumulation of SP-B protein during culture indicate posttranscriptional regulation which could reflect changes in rate of translation and/or protein degradation. We speculate that processing of precursor SP-B to the mature form increases as epithelial cells differentiate during culture (or in vivo) and acquire multivesicular bodies and lamellar bodies (32). The observations that monomer forms of SP-B were not detected in embryonic rat lung and glucocorticoid-treated $\mathrm{H}-441$ cells, both of which contain SP-B mRNA but not lamellar bodies, support this possibility $(12,33)$. Further studies using pulsechase protocols will be useful in defining SP-B synthesis, processing, and stability in the developing lung.

The distribution of riboprobe hybridization signal and immunostaining in cultured control tissue was nonuniform with some individual cells of a tubule or clusters of epithelial cells having higher levels of signal. By contrast, most cells in most tubules of dexamethasone-treated tissue were uniformly positive. These patterns are similar to the morphologic appearance of control and treated tissue with regard to type II cell differentiation (20) and are consistent with glucocorticoid causing a coordinated precocious differentiation of all epithelial cells into type II cells. It is possible that the decreased hybridization signal in some tubules (e.g. Fig. $1 b)$ is artifactual (e.g. nonuniform coating with emulsion or variation in the plane of sectioning), but it seems more likely that this variability reflects regional differences in rate of cytodifferentiation.

The response to dexamethasone is quantitatively similar for SP-B mRNA and protein. In this study we found a $\sim 3$-fold increase in both SP-B mRNA and protein in explants exposed to dexamethasone. Previously, Whitsett et al. (16) described a 3-fold increase by dexamethasone in surfactant proteolipid using antiserum that recognized both SP-B and SP-C. These observations indicate that glucocorticoids increase the content of SP-B protein primarily by increasing mRNA content, in agreement with recent data that glucocorticoids increase both the rate of transcription and stability of SP-B mRNA (13).

An earlier study with cultured human fetal lung described $\left[{ }^{35} \mathrm{~S}\right]$ methionine incorporation into immunoprecipitable proteins of 42,25 , and $8 \mathrm{kD}$ under reducing conditions, representing precursor and processed forms of SP-B protein (14). We found on Western blot that the primary immunoreactive SP-B protein in cultured tissue was the mature form $(\sim 6.5 \mathrm{kD})$ with lower levels of 26- and 42-kD forms. This pattern resembled that of adult lung indicating that there is appropriate processing of SP-B in cultured fetal lung and that the predominant SP-B form quantitated by the immunoblot assay is the mature protein.

Cellular distribution and regulation of SP-B has been examined in rodents. In adult lung SP-B mRNA and proprotein are localized to bronchial, bronchiolar, and alveolar epithelium, with an alveolar distribution consistent with type II cells (11, 34). In vivo dexamethasone treatment increased the hybridization signal over bronchiolar and alveolar cells of both fetal and postnatal animals (11). In a study with fetal rat lung in explant culture (10), dexamethasone treatment increased levels of 
SP-B mRNA and the proportion of bronchiolar and alveolar cells expressing the gene similar to our results with human lung. To our knowledge there are no published data describing hormonal effects on SP-B protein in animal models.

The importance of SP-B for normal lung function is becoming increasingly evident as a result of recent studies with antibodies (2-4) and the report of a congenital deficiency of SP-B (6). Many prematurely born infants are likely deficient in surfactant proteins as well as lipids and consequently experience respiratory distress and long-term lung disease. Prenatal treatment with corticosteroids reduces the incidence of respiratory distress syndrome and improves overall survival in premature infants. It is likely that induction of SP-B protein occurs with steroid therapy and is an important component of the protective response.

Acknowledgments. The authors thank John Gonzales, Kolawole Solarin, Chi Kim, and Kathy Notarfrancesco for technical assistance and Sandy Mosiniak for preparing the manuscript.

\section{REFERENCES}

1. Weaver TE, Whitsett JA 1991 Function and regulation of expression of pulmonary surfactant-associated proteins. Biochem J 273:249-264

2. Kobayashi T, Robertson B, Grossmann G, Nitta K, Curstedt T, Suzuki Y 1992 Exogenous porcine surfactant (Curosurf) is inactivated by monoclonal antibody to the surfactant-associated hydrophobic protein SP-B. Acta Paediatr 81:665--671

3. Robertson B, Kobayashi T, Gansuka M, Grossman G, Li WZ, Suzuki Y 1991 Experimental neonatal respiratory failure induced by a monoclonal antibody to the hydrophobic surfactant associated protein SP-B. Pediatr Res 30:239-243

4. Suzuki Y, Robertson B, Fujita Y, Grossman G, Kogishi K., Curstedt T 1992 Lung protein leakage in respiratory failure induced by a hybridoma making monoclonal antibody to the hydrophobic surfactant-associated polypeptide SP-B. Int J Exp Pathol 73:325-333

5. Rider ED, Ikegami M, Whitsett JA, Hull W, Absolom D, Jobe AH 1993 Treatment responses to surfactants containing natural surfactant proteins in preterm rabbits. Am Rev Respir Dis 147:669-676

6. Nogee LM, DeMello DE, Dehner LP, Colten HR 1993 Brief report: deficiency of pulmonary surfactant protein $\mathrm{B}$ in congenital alveolar proteinosis. $\mathrm{N}$ Engl $\mathrm{J}$ Med 328:406-410

7. Liley HG, White RT, Warr RG, Benson BJ, Hawgood S, Ballard PL 1989 Regulation of messenger RNAs for the hydrophobic surfactant proteins in human lung. J Clin Invest 83:1191-1197

8. Phelps DS, Floros J 1988 Localization of surfactant protein synthesis in human lung by in situ hybridization. Am Rev Respir Dis 137:939-942

9. Ballard PL 1989 Hormonal regulation of pulmonary surfactant. Endocr Rev 10:165181

10. Floros J, Gross I, Nichols K, Veletza SV, Dynia D, Lu H, Wilson CM, Petrec SM 1991 Hormonal effects on the surfactant protein B (SP-B) mRNA in cultured fetal rat lung. Am J Respir Cell Mol Biol 4:449-454

11. Phelps DS and Floros $\mathrm{J} 1991$ Dexamethasone in vivo raises surfactant protein B mRNA in alveolar and bronchiolar epithelium. Am J Physiol 260:L146-L152

12. O'Reilly MA, Gazdar AF, Morris RE, Whitsett JA 1988 Differential effects of glucocorticoid on expression of surfactant proteins in a human lung adenocarcinoma cell line. Biochim Biophys Acta 970:194

13. Venkatesh VC, Ballard PL, Ertsey R, Iannuzzi DM 1993 Glucocorticoid regulation of the genes for pulmonary surfactant proteins SP-B and SP-C. Am J Respir Cell Mol Biol 8:222-228
14. Weaver TE, Virender KS, Sawtell N, Hull WM, Whitsett JA 1988 Identification of surfactant proteolipid SP-B in human surfactant and fetal lung. J Appl Physiol 65:982-987

15. Stahlman MT, Gray ME, Whitsett JA 1992 The ontogeny and distribution of surfactant protein B in human fetuses and newborns. J Histochem Cytochem 40:1471-1480

16. Whitsett JA, Weaver TE, Clark JC, Sawtell N, Glasser SW, Korfhagen TR, Hull WM 1987 Glucocorticoid enhances surfactant proteolipid Phe and pVal synthesis and RNA in fetal lung. J Biol Chem 262:15618-15623

17. Pryhuber GS, Hull WM, Fink I, McMahan MJ, Whitsett JA 1991 Ontogeny of surfactant proteins $\mathrm{A}$ and $\mathrm{B}$ in human amniotic fluid as indices of fetal lung maturity. Pediatr Res 30:597-605

18. Ballard PL, Beers MF, Floros J, Gonzales LW, Liley HG, Shuman H 1994 Cellular localization and regulation of surfactant protein B in human fetal lung. Clin Res 42:52(abstr)

19. Gonzales LW, Ballard PL, Beers MF, Floros J, Liley HG, Shuman H. 1994 Surfactant protein B in human fetal lung: cellular localization and regulation. Am Rev Respir Dis 149:501(abstr)

20. Gonzales LW, Ballard PL, Ertsey R, Williams MC 1986 Glucocorticoids and thyroid hormones stimulate biochemical and morphological differentiation of human fetal lung in organ culture. J Clin Endocrinol Metab 62:678-691

21. Jacobs KA, Phelps DS, Steinbrink R, Fisch J, Kriz R, Mitsock L, Dougherty JP, Taeusch HW, Floros J 1987 Isolation of a cDNA clone encoding a high molecular weight precursor to a $6-\mathrm{kDa}$ pulmonary surfactant-associated protein. J Biol Chem 262:9808-9811

22. Hoefler H, Childers H, Montminy MR, Lechan RM, Goodman RH, Wolfe HJ 1986 In situ hybridization methods for the detection of somatostatin mRNA in tissue sections using antisense probes. Histochem J 18:57-64

23. Beers MF, Bates SR, Fisher AB 1992 Differential extraction for the rapid purification of bovine surfactant protein B. Am J Physiol 262:L773-L778

24. Williams MC, Hawgood S, Schenk DB, Lewicki J, Phelps MN, Benson B 1988 Monoclonal antibodies to surfactant proteins SP 28:36 label canine Type II and nonciliated bronchiolar cells by immunofluorescence. Am Rev Respir Dis 137:399. 405

25. Beers ML, Wali A, Eckenhoff MF, Feinstein SI, Fisher JH, Fisher AB 1992 An antibody with specificity for surfactant protein $C$ precursors: identification of ProSP-C in rat lung. Am J Respir Cell Mol Biol 7:368-378

26. Bradford MM $1976 \mathrm{~A}$ rapid and sensitive method for the quantitation of micrograms quantities of protein utilizing the principle of protein-dye binding. Ann Biochem $72: 248-254$

27. Johannsen J, Curstedt T, Persson P, Robertson B, Lowenadler B, Jornvall H 1990 Hydrophobic surfactant proteins SP-B and SP-C: special analytical problems. In: Jornvall H (ed) Methods in Protein Sequence Analysis. Birkhauser Verlag, Basel, pp 197-204

28. Schagger H, von Jagow G 1987 Tricine-sodium dodecyl sulfate gel electrophoresis for the separation of proteins in the range from 1 to $100 \mathrm{kDa}$. Anal Biochem 166:368-379

29. Froh D, Ballard PL, Williams MC, Gonzales J, Goerke J, Odom MW, Gonzales LK 1990 Lamellar bodies of cultured human fetal lung: content of surfactant protein A (SP-A), surface film formation, and structural transformation in vitro. Biochim Biophys Acta 1052:78-89

30. Acarregui MJ, Snyder JN, Mitchell MD, Mendelson CR 1990 Prostaglandins regulate surfactant protein A (SP-A) gene expression in human fetal lung in vitro. Endocrinology 127:1105-113

31. Ballard PL, Gonzales LW, Williams MC, Roberts JM, Jacobs MM 1991 Differentiation of type II cells during explant culture of human fetal lung is accelerated by endogenous prostanoids and adenosine $3^{\prime}, 5^{\prime}$-monophosphate. Endocrinology 128:2916-2924

32. Voorhout WF, Weaver TE, Haagsman HP, Geuze HJ, van Golde LMG 1993 Biosynthetic routing of pulmonary surfactant proteins in alveolar type II cells. Microsc Res Tech 26:366-373

33. Wang J, Souza P, Kuliszewski M, Tanswell AK, Post M 1994 Expression of surfactant proteins in embryonic rat lung. Am J Respir Cell Mol Biol 10:222-229

34. Wikenheiser KA, Wert SE, Wispe JR, Stahlman M, D'Amore-Bruno M, Singh G Katyal SL, Whitsett JA 1992 Distinct effects of oxygen on surfactant protein B expression in bronchiolar and alveolar epithelium. Am J Physiol 262:L32-L39 